Supporting information for

\title{
Convenient Route to Heterometallic Group 4-Zinc Precursors for Binary Oxide Nanomaterials
}

\author{
Rafał Petrus, ${ }^{\text {aa }}$ Katarzyna Chomiak, ${ }^{\mathrm{b}}$ Józef Utko, ${ }^{\mathrm{c}}$ Magdalena Wilk-Kozubek, ${ }^{\mathrm{b}}$ Tadeusz Lis, ${ }^{\mathrm{c}}$ \\ Joanna Cybińska ${ }^{b, c}$ and Piotr Sobota ${ }^{* b}$
}

\begin{abstract}
aFaculty of Chemistry, Wrocław University of Science and Technology, 23 Smoluchowskiego, 50-370 Wrocław, Poland

${ }^{b}$ Łukasiewicz Research Network - PORT Polish Center For Technology Development, 147 Stablowicka, 54-066 Wrocław, Poland

${ }^{\mathrm{c} F a c u l t y}$ of Chemistry, University of Wrocław, 14 F. Joliot-Curie, 50-383 Wrocław, Poland
\end{abstract}

Corresponding author:

Dr. Rafał Petrus, rafal.petrus@pwr.edu.pl

Prof. Dr. Piotr Sobota, piotr.sobota@port.org.pl

\section{Contents}

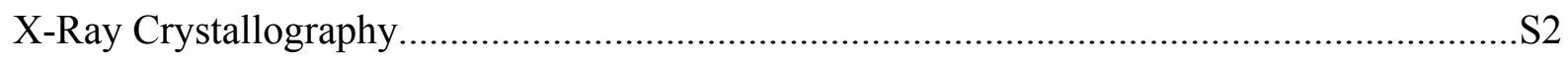

NMR, IR and XRD data for oily liquids synthesized in the reaction of $\mathrm{Cp}_{2} \mathrm{TiCl}_{2}$ with 2 equiv.

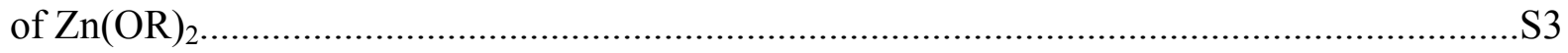

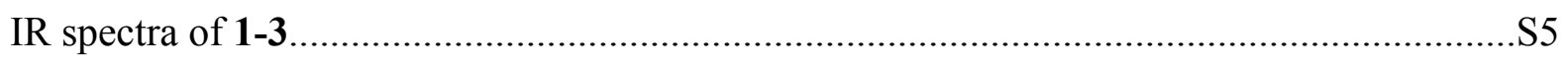

TEM-EDX and SAED analysis of obtained oxide materials................................................. 7

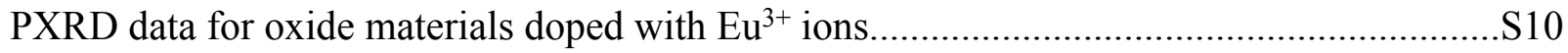

Photoluminescence data for oxide materials doped with $\mathrm{Eu}^{3+}$ ions...........................................S11 


\section{Crystallographic Data for Compounds 1-3.}

Table S1. Crystal and data collection parameters for compounds 1-3.

\begin{tabular}{|c|c|c|c|c|}
\hline Crystal & 1 & $\mathbf{2} \cdot 2\left(\mathrm{C}_{3} \mathrm{H}_{8} \mathrm{O}_{2}\right)$ & 3.2 $\left(\mathrm{C}_{3} \mathrm{H}_{8} \mathrm{O}_{2}\right)$ & {$\left[\mathrm{Zn}_{2}(\mu-\mathrm{Cl})_{2}\left(\eta^{2}-\mathrm{HOR}\right)_{2} \mathrm{Cl}_{2}\right]$} \\
\hline Chemical formula & $\mathrm{C}_{17} \mathrm{H}_{25} \mathrm{Cl}_{2} \mathrm{O}_{3} \mathrm{TiZn}$ & $\mathrm{C}_{51} \mathrm{H}_{124} \mathrm{Cl}_{6} \mathrm{O}_{38} \mathrm{Zn}_{7} \mathrm{Zr}_{3}$ & $\mathrm{C}_{51} \mathrm{H}_{124} \mathrm{Cl}_{6} \mathrm{O}_{38} \mathrm{Zn}_{7} \mathrm{Hf}_{3}$ & $\mathrm{C}_{6} \mathrm{H}_{16} \mathrm{C}_{14} \mathrm{O}_{4} \mathrm{Zn}_{2}$ \\
\hline Formula Mass & 461.54 & 2289.44 & 2551.25 & 424.73 \\
\hline Crystal system & Monoclinic & Trigonal & Trigonal & Monoclinic \\
\hline Space group & $P 2_{1} / \mathrm{n}$ & $P-3 c 1$ & $P-3 c 1$ & $P 2_{1} / \mathrm{c}$ \\
\hline$a / \AA ̊$ & $8.3134(3)$ & $16.407(2)$ & $16.408(2)$ & $13.999(2)$ \\
\hline$b / \AA ̊$ & $16.3009(5)$ & & & $7.1968(13)$ \\
\hline$c / \AA$ & $14.3452(4)$ & $39.224(5)$ & $39.153(4)$ & $14.836(3)$ \\
\hline \multicolumn{5}{|l|}{$\alpha /^{\circ}$} \\
\hline$\beta /^{\circ}$ & $92.116(3)$ & & & $94.90(2)$ \\
\hline \multicolumn{5}{|l|}{$\gamma /{ }^{\circ}$} \\
\hline Unit cell volume $/ \AA^{3}$ & $1942.68(11)$ & $9144(3)$ & $9129(2)$ & $1489.2(5)$ \\
\hline Temperature/K & $100(2)$ & $80(2)$ & $80(2)$ & $100(2)$ \\
\hline$Z$ & 4 & 4 & 4 & 4 \\
\hline Radiation type & $\mathrm{MoK} \alpha$ & $\mathrm{MoK} \alpha$ & $\mathrm{MoK} \alpha$ & $\mathrm{MoK} \alpha$ \\
\hline Absorption coefficient, $\mu / \mathrm{mm}^{-1}$ & 1.932 & 2.380 & 5.450 & 3.932 \\
\hline No. of reflections measured & 11140 & 25600 & 18067 & 24540 \\
\hline No. of independent reflections & 4669 & 8553 & 6896 & 7045 \\
\hline No. of observed reflections $(I>2 \sigma(I))$ & 3883 & 6988 & 5719 & 5945 \\
\hline$R_{\text {int }}$ & 0.0553 & 0.0307 & 0.0317 & 0.0487 \\
\hline Final $R_{l}$ values $(I>2 \sigma(I))$ & 0.0468 & 0.0330 & 0.0311 & 0.0395 \\
\hline Final $w R\left(F^{2}\right)$ values $(I>2 \sigma(I))$ & 0.1174 & 0.0686 & 0.0550 & 0.1011 \\
\hline Final $R_{l}$ values (all data) & 0.0581 & 0.0474 & 0.0431 & 0.0487 \\
\hline Final $w R\left(F^{2}\right)$ values (all data) & 0.1290 & 0.0745 & 0.0593 & 0.1091 \\
\hline Goodness of fit on $F^{2}$ & 1.082 & 1.080 & 1.090 & 1.037 \\
\hline$\Delta \rho \max / \mathrm{e} \AA^{-3}$ & 1.45 & 0.59 & 1.26 & 0.85 \\
\hline$\Delta \rho \min / \AA^{-3}$ & -0.79 & -0.51 & -0.90 & -1.47 \\
\hline
\end{tabular}




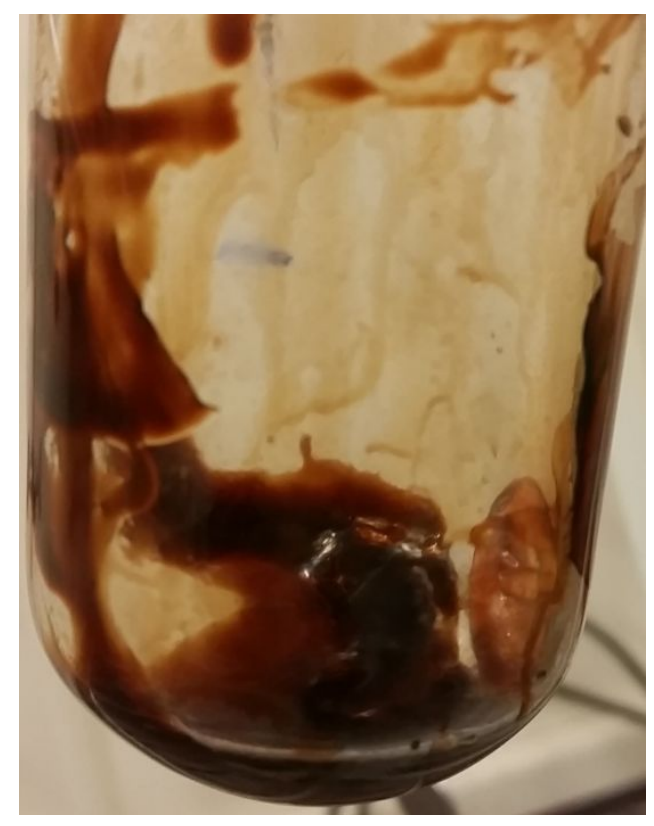

Figure S1. Oily liquids obtained in the reaction of $\mathrm{Cp}_{2} \mathrm{TiCl}_{2}$ with 2 equiv. of $\mathrm{Zn}(\mathrm{OR})_{2}$.

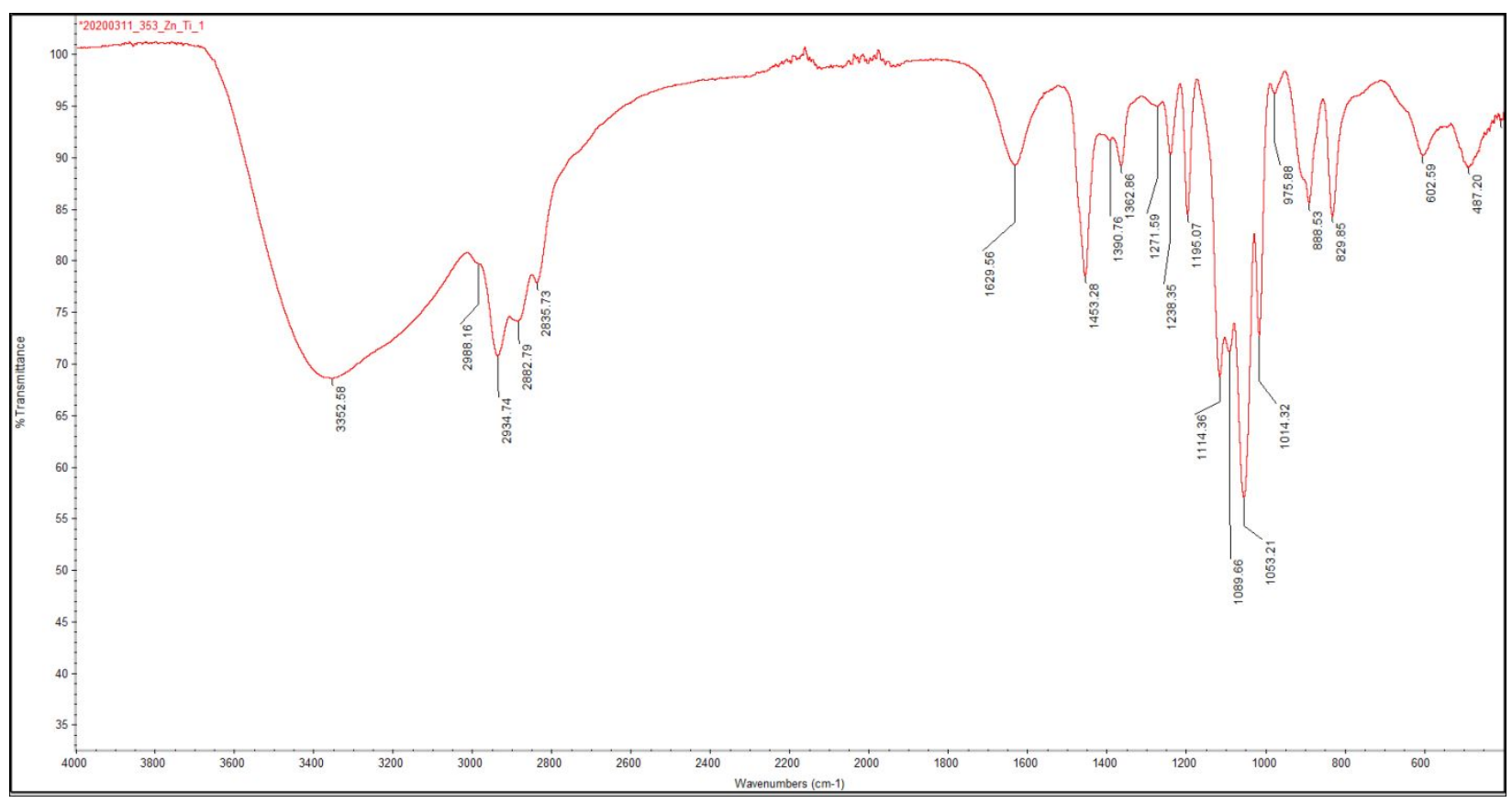

Figure S2. FTIR-ATR spectra of oily liquids obtained in the reaction of $\mathrm{Cp}_{2} \mathrm{TiCl}_{2}$ with 2 equiv. of $\mathrm{Zn}(\mathrm{OR})_{2}$. 


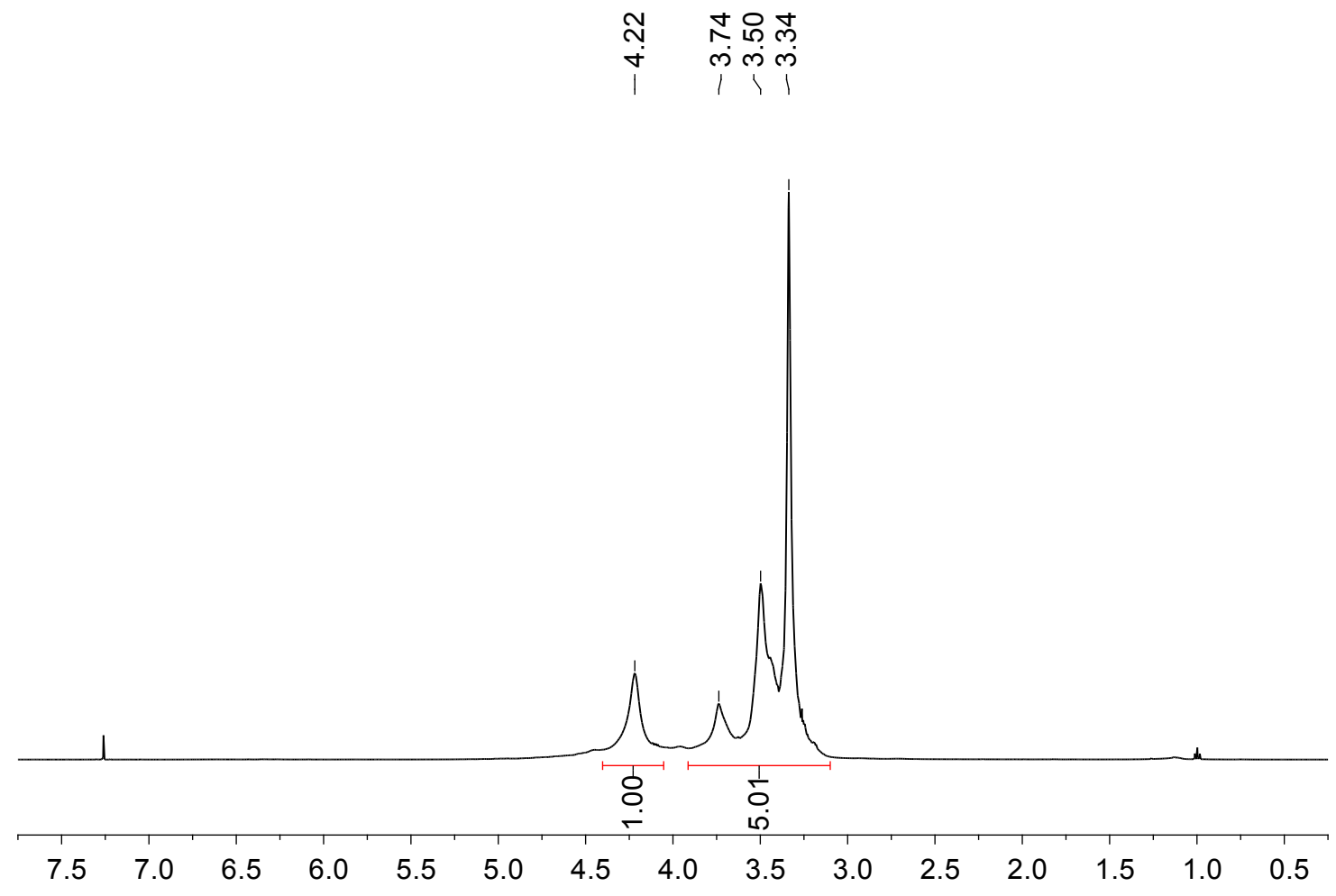

Figure S3. ${ }^{1} \mathrm{H}$ NMR spectra in $\mathrm{CDCl}_{3}$ of oily liquids obtained in the reaction of $\mathrm{Cp}_{2} \mathrm{TiCl}_{2}$ with 2 equiv. of $\mathrm{Zn}(\mathrm{OR})_{2}$.

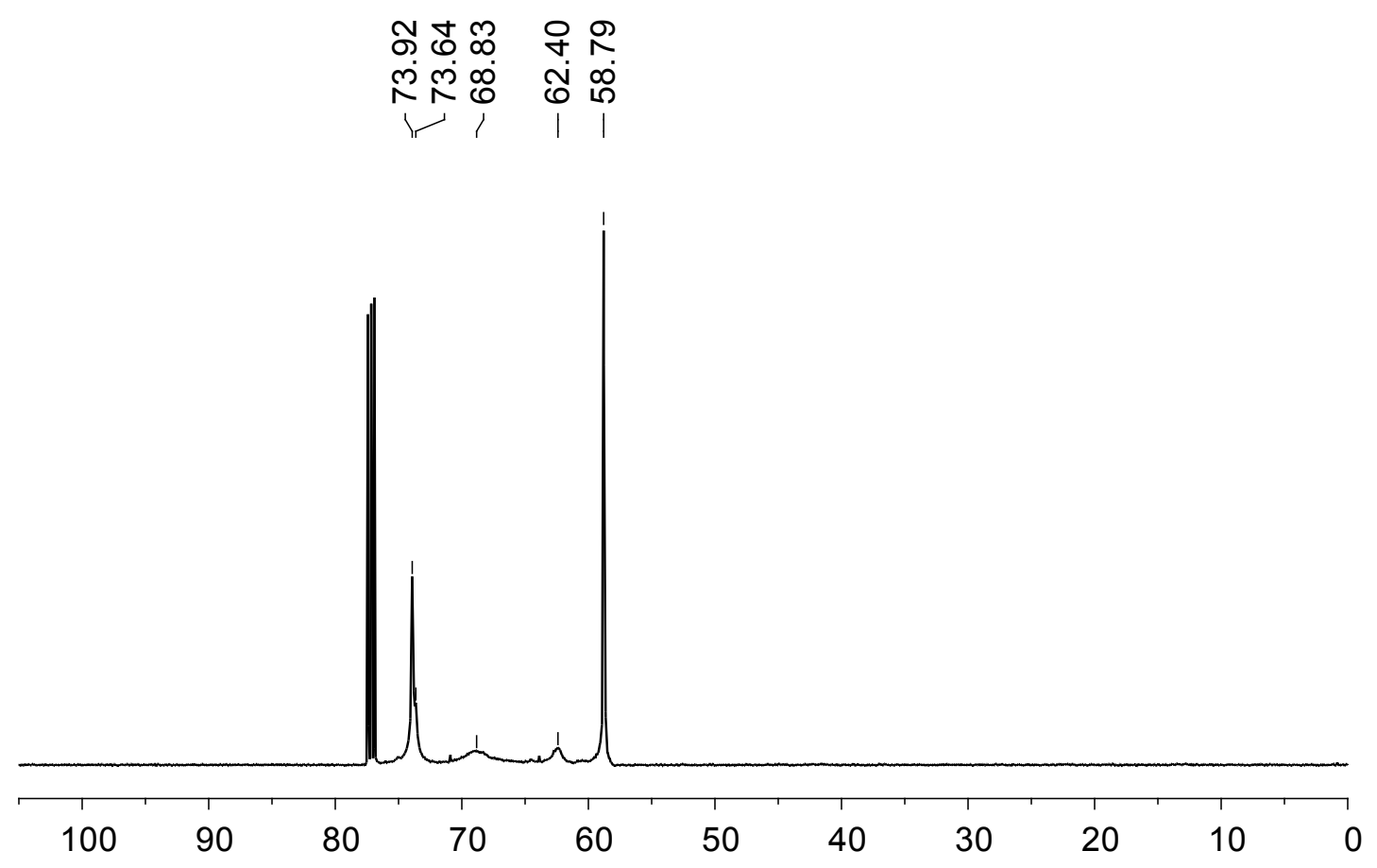

Figure S4. ${ }^{13} \mathrm{C}$ NMR spectra in $\mathrm{CDCl}_{3}$ spectra of oily liquids obtained in the reaction of $\mathrm{Cp}_{2} \mathrm{TiCl}_{2}$ with 2 equiv. of $\mathrm{Zn}(\mathrm{OR})_{2}$. 


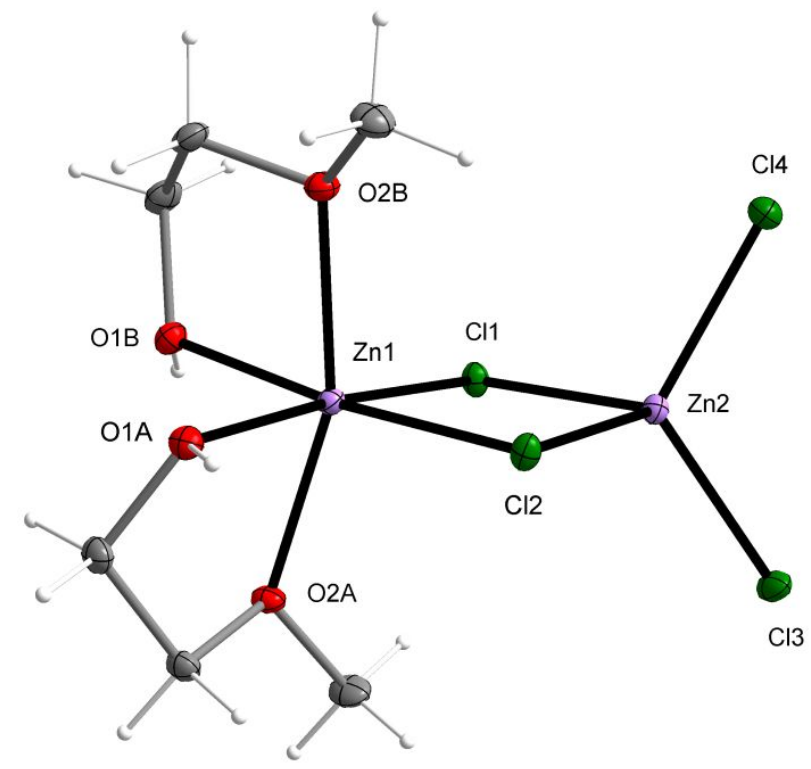

Figure S5. Molecular structure of $\left[\mathrm{Zn}_{2}(\mu-\mathrm{Cl})_{2}\left(\eta^{2}-\mathrm{HOR}\right)_{2} \mathrm{Cl}_{2}\right]$. Displacement ellipsoids are drawn at the $30 \%$ probability level.

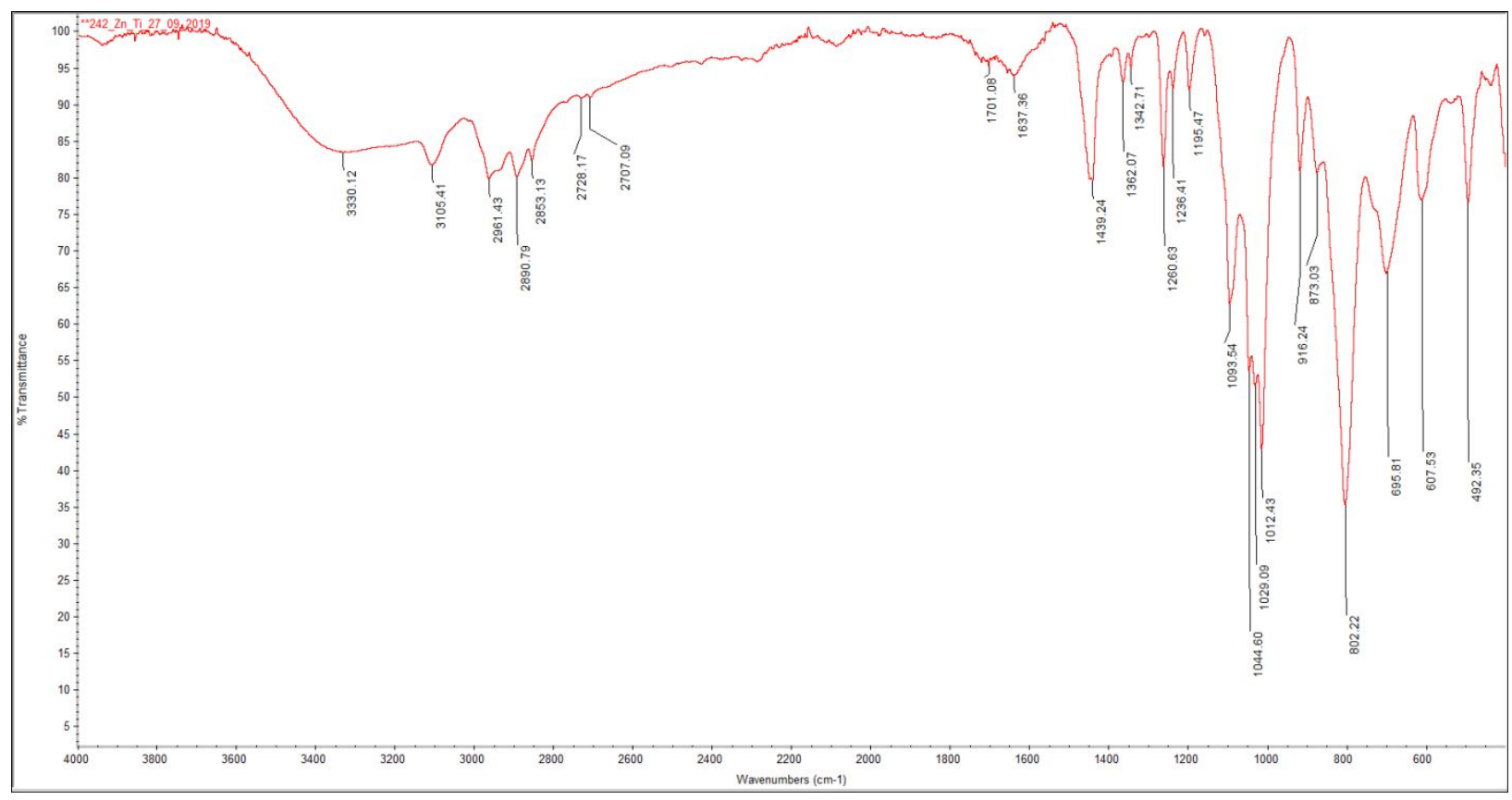

Figure S6. FTIR-ATR spectra of $\mathbf{1}$. 


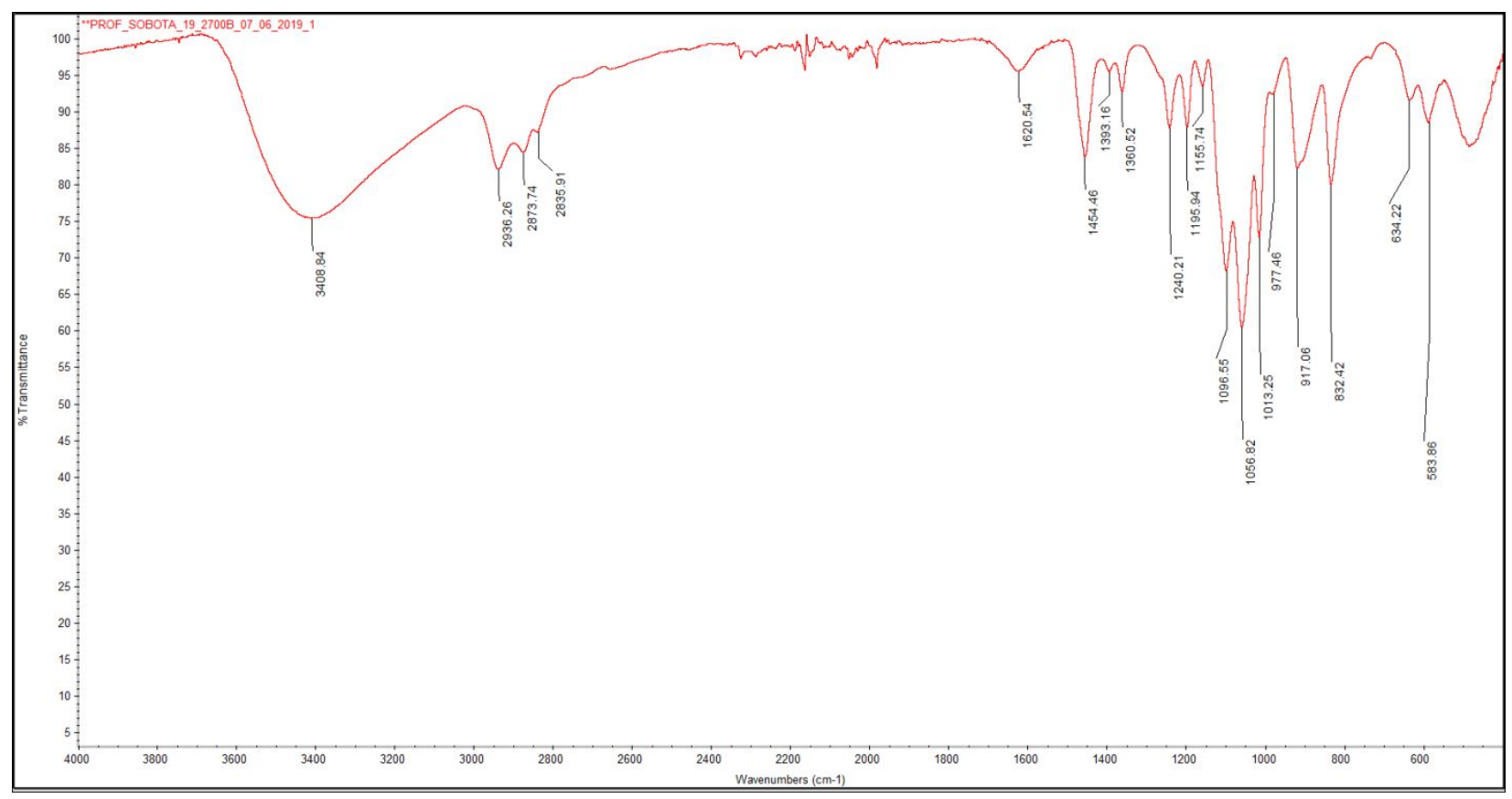

Figure S7. FTIR-ATR spectra of 2.

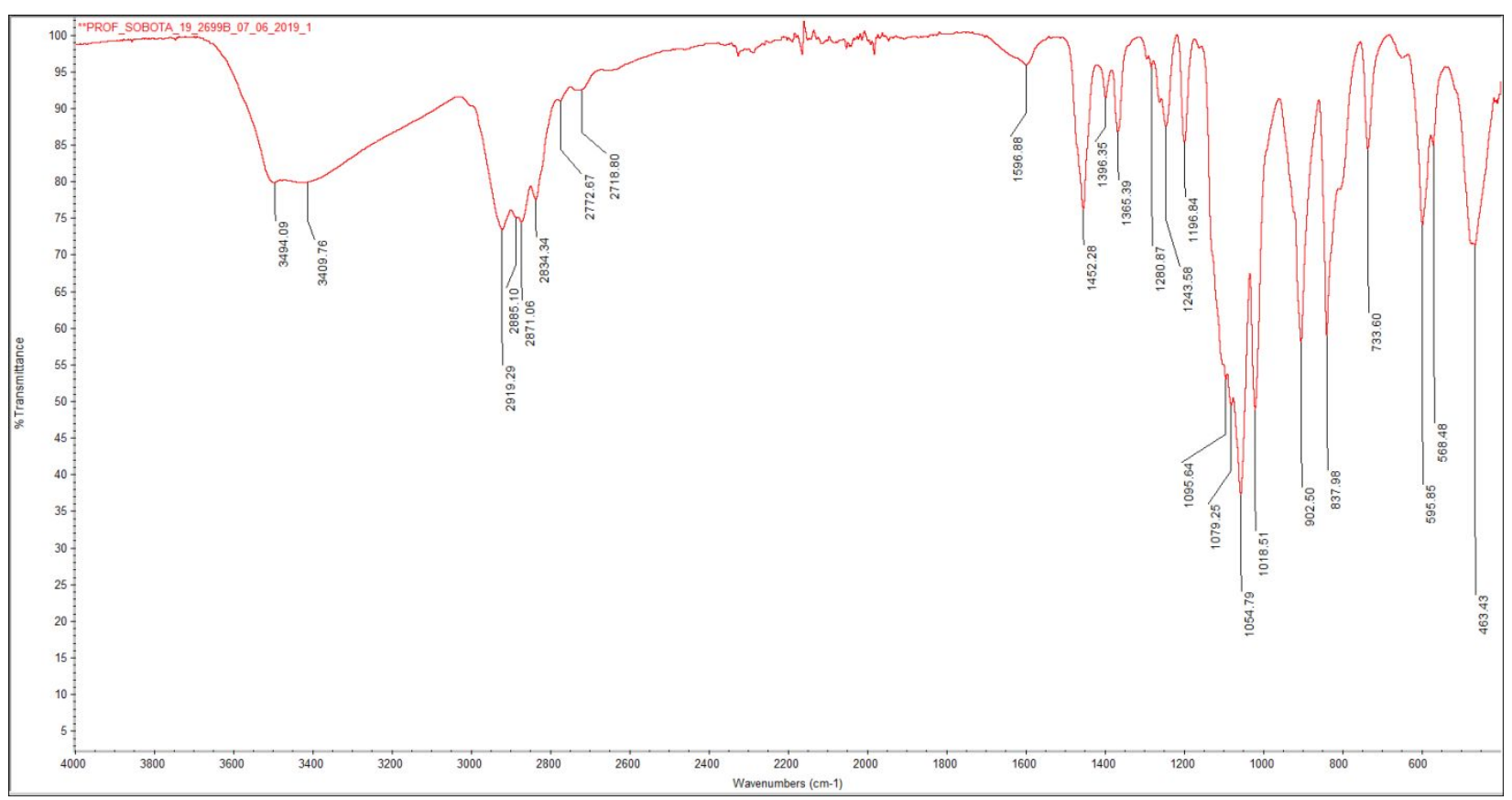

Figure S8. FTIR-ATR spectra of 3 . 


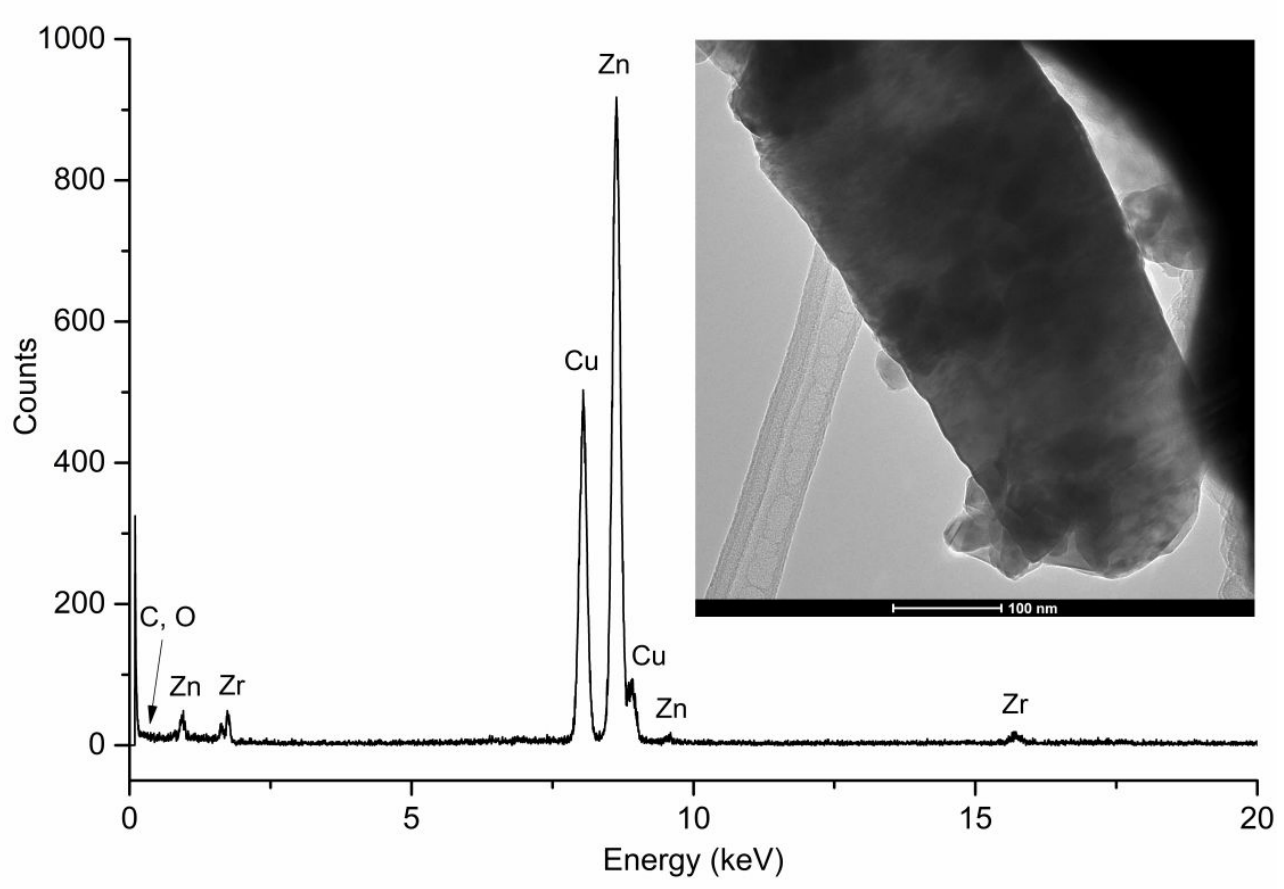

Figure S9. TEM-EDX analysis of the $\mathrm{ZnO}$ nanowires in the oxide material obtained by thermolysis of 2 at $800{ }^{\circ} \mathrm{C}$.

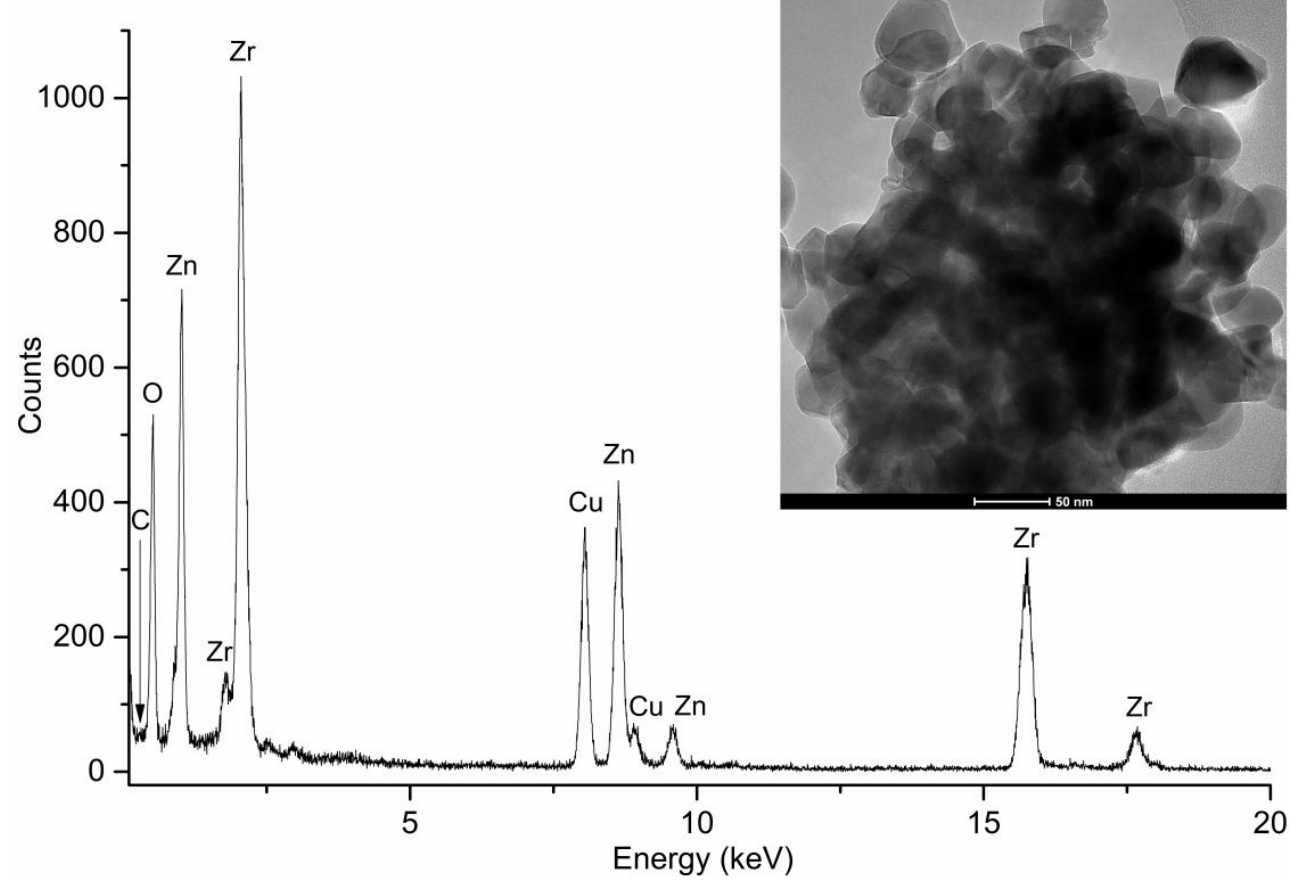

Figure S10. TEM-EDX analysis of the mixture of $\mathrm{ZrO}_{2}$ and $\mathrm{ZnO}$ nanoparticles obtained by thermolysis of 2 at $800{ }^{\circ} \mathrm{C}$. 


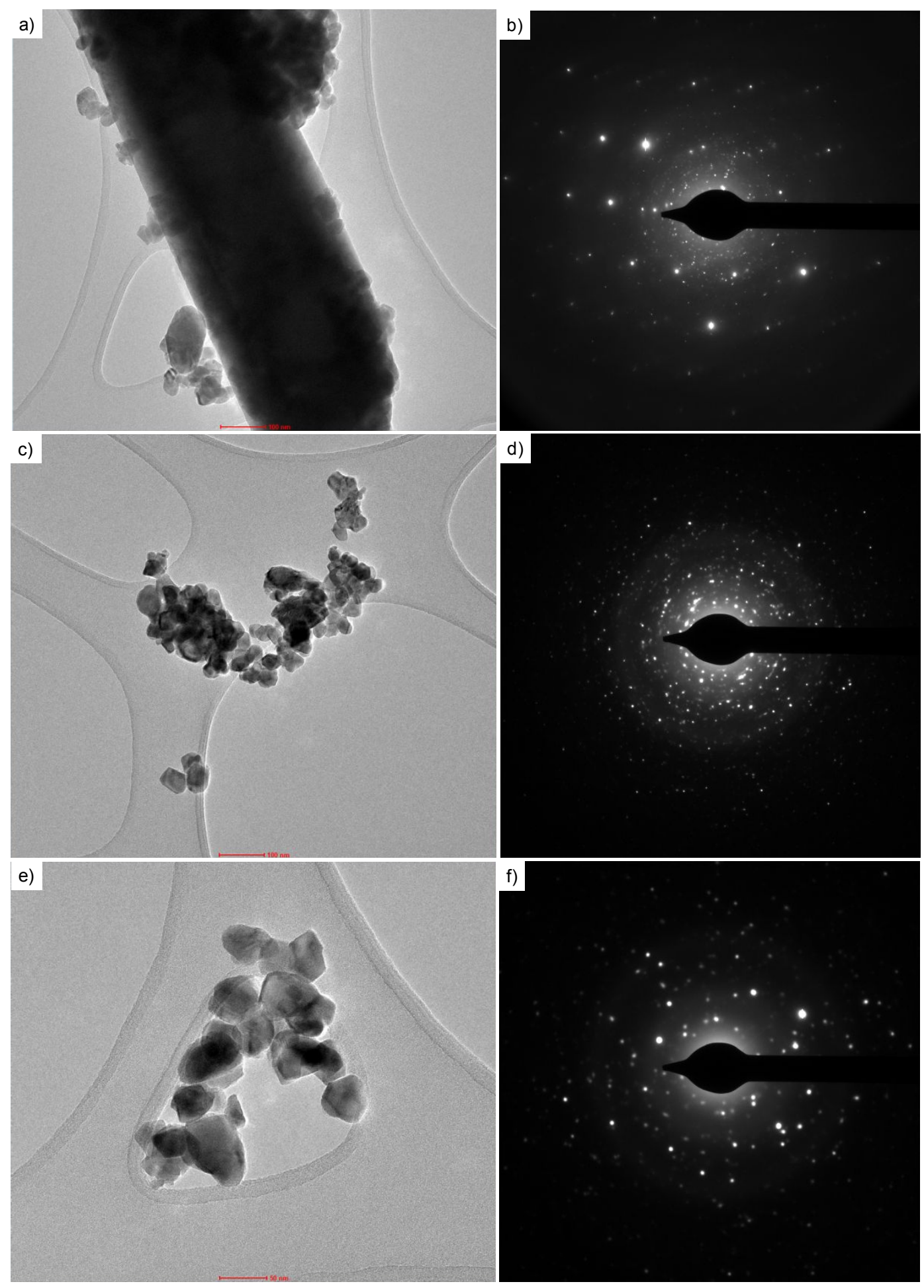

Figure S11. TEM images and SAED patterns of the $\mathrm{ZnO}$ nanowires $(\mathrm{a}-\mathrm{b})$ and $\mathrm{ZrO}_{2}$ nanoparticles (c - f). 


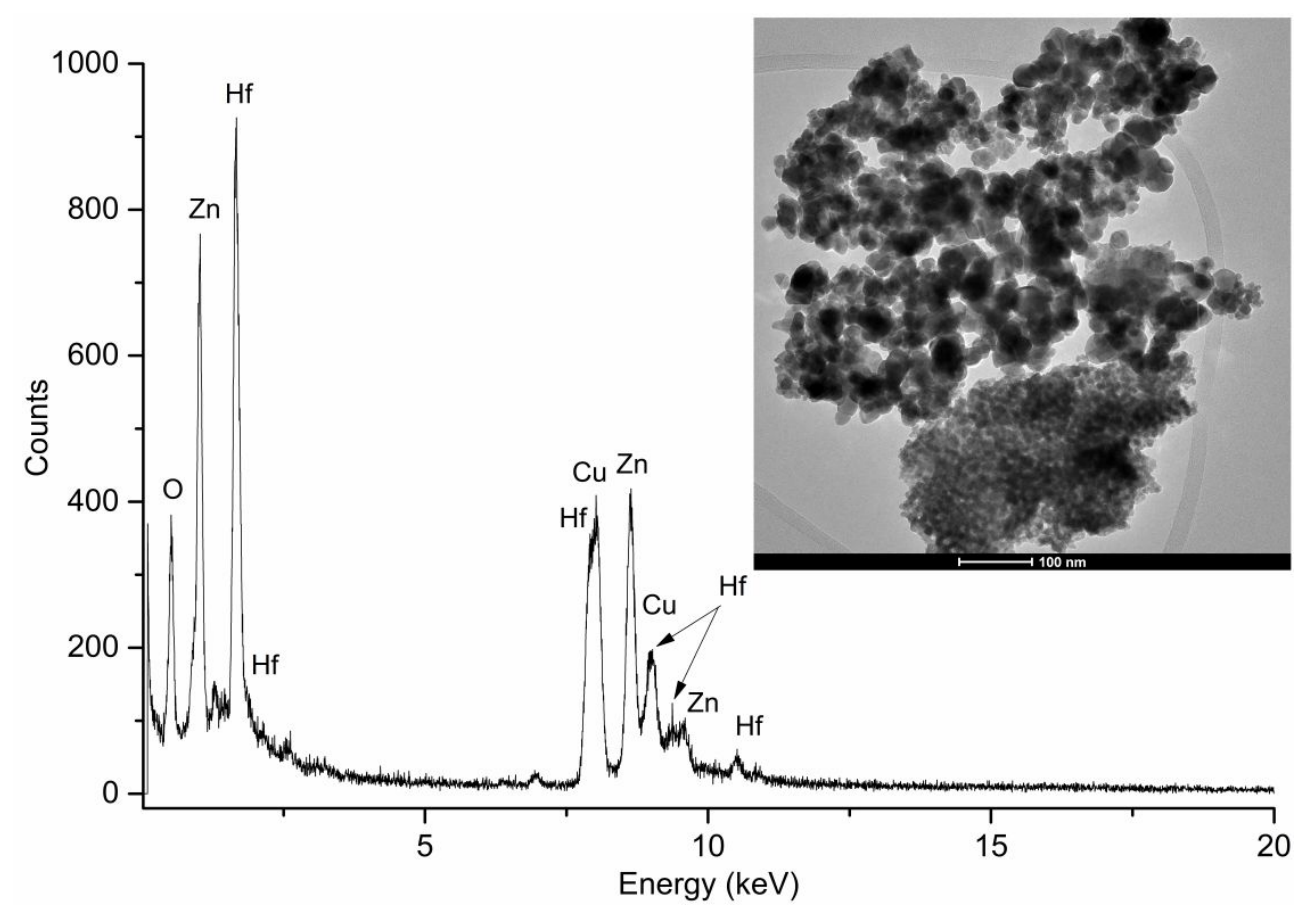

Figure S12. TEM-EDX analysis of powders obtained by thermolysis of 3 at $800{ }^{\circ} \mathrm{C}$. 


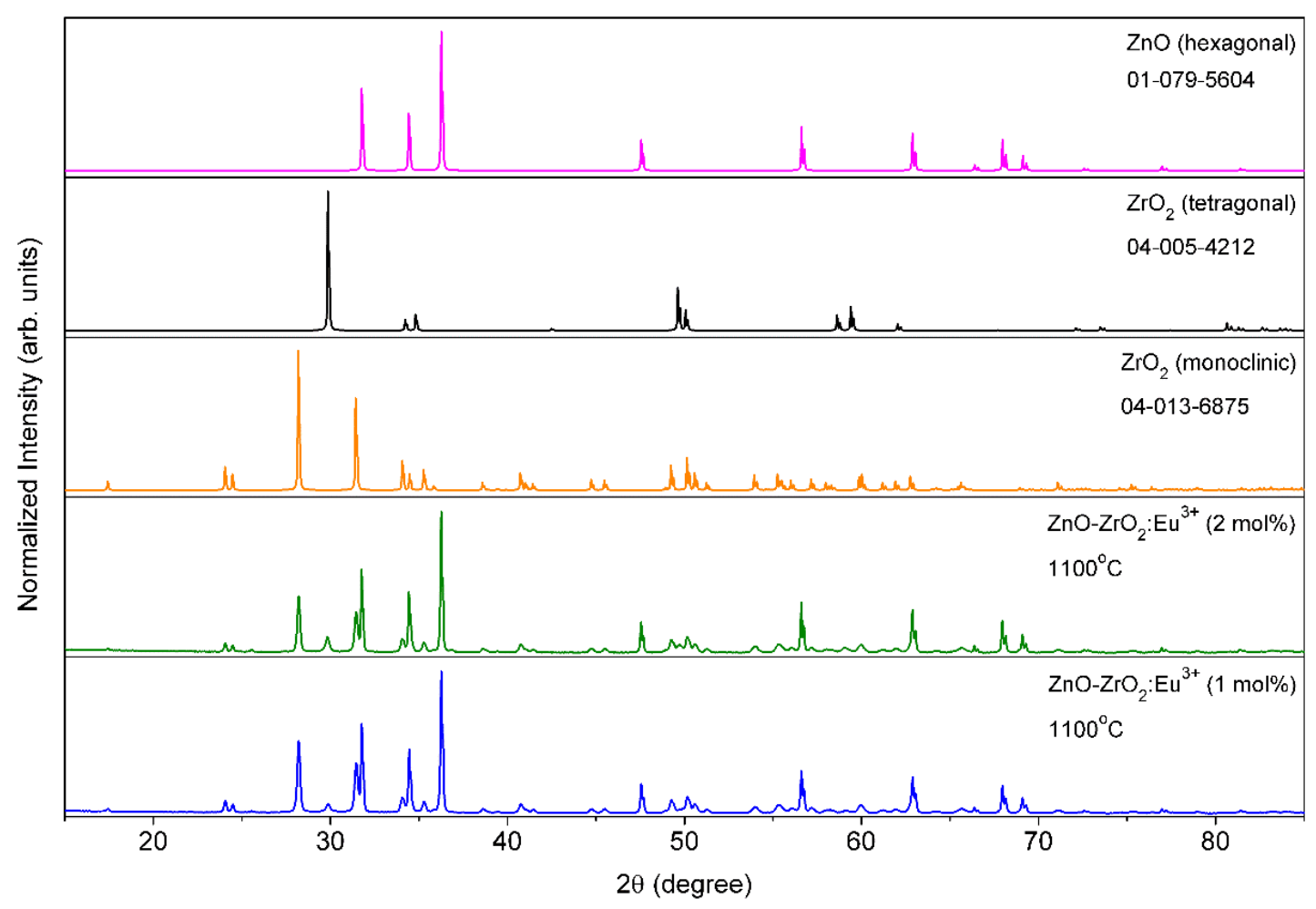

Figure S13. Powder XRD patterns of $\mathrm{Eu}^{3+}$-doped $\mathrm{ZnO}-\mathrm{ZrO}_{2}$ materials.

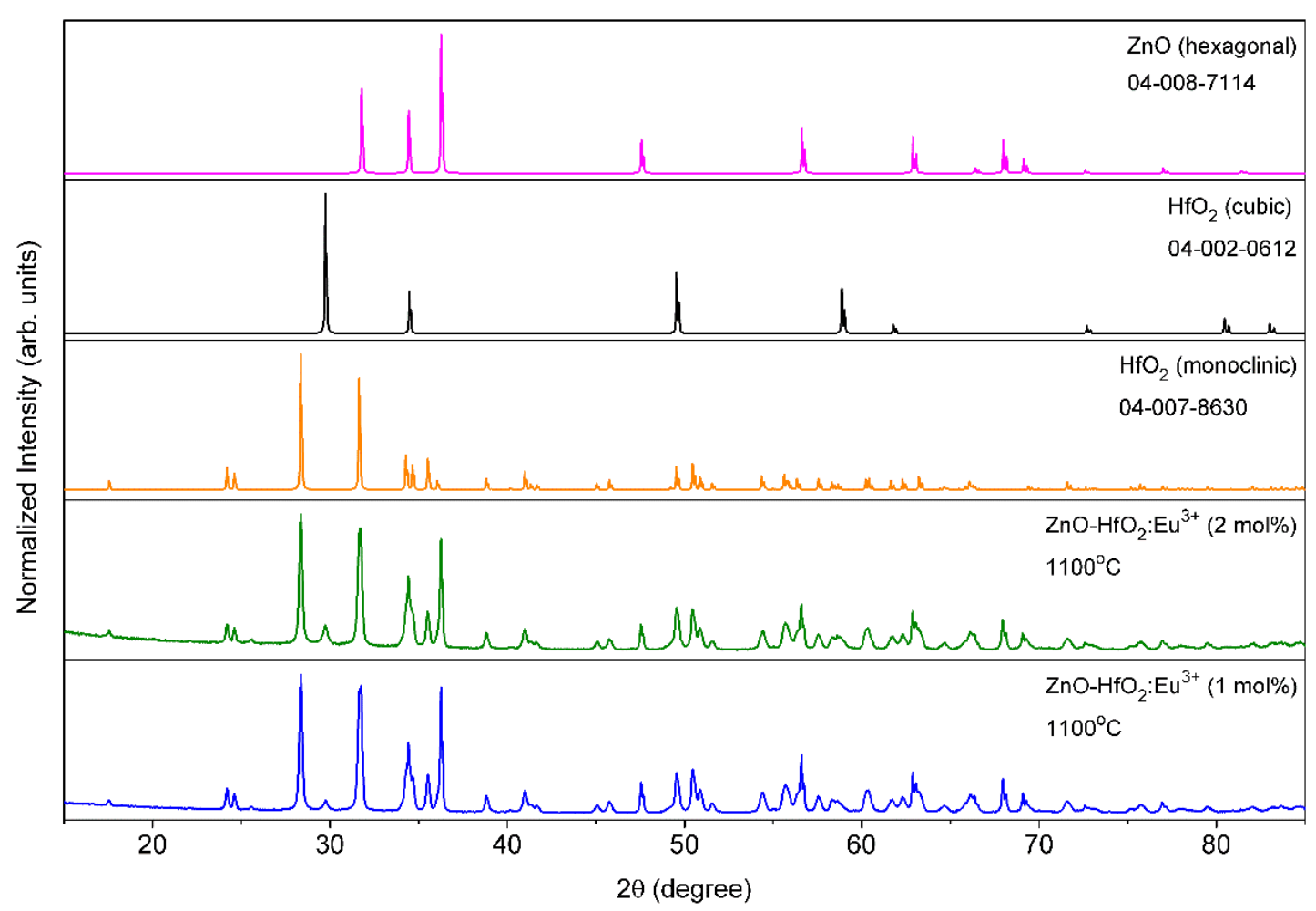

Figure S14. Powder XRD patterns of $\mathrm{Eu}^{3+}$-doped $\mathrm{ZnO}-\mathrm{HfO}_{2}$ materials. 
(a)

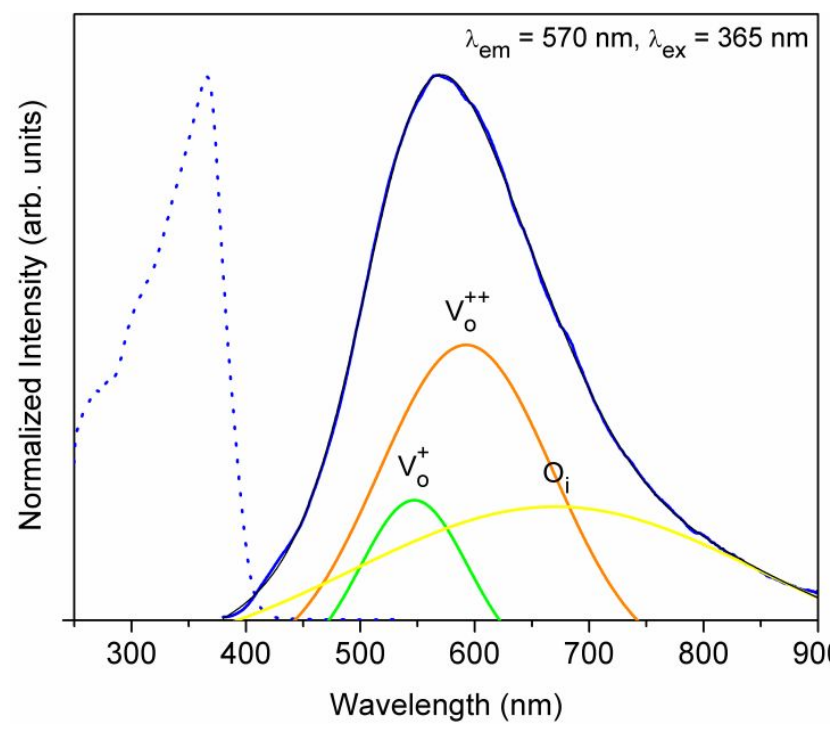

(b)

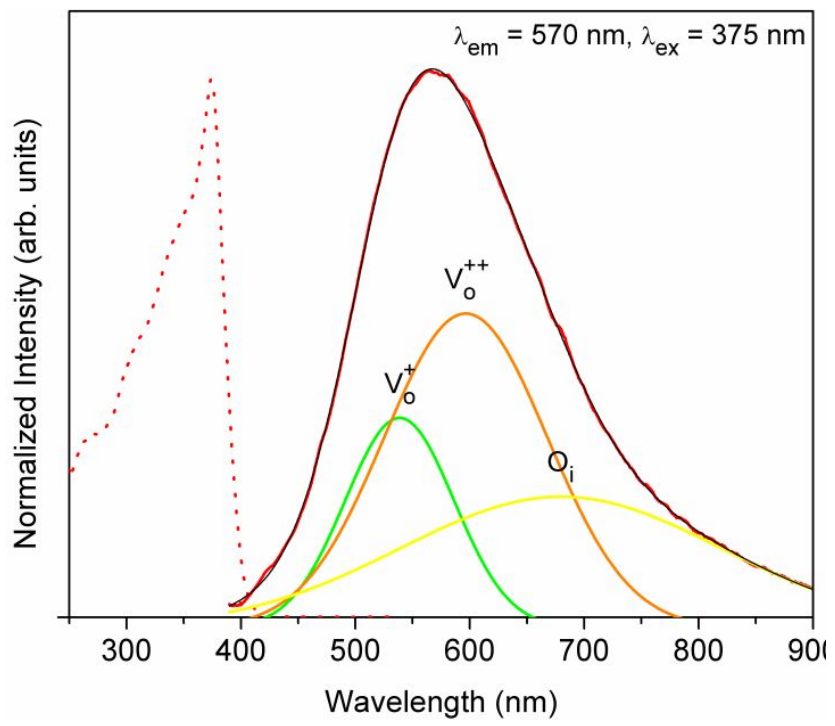

Figure S15. (a) Photoluminescence excitation and emission spectra of undoped $\mathrm{ZnO}-\mathrm{ZrO}_{2}$ system, and a deconvolution of the emission spectrum. (b) Photoluminescence excitation and emission spectra of undoped $\mathrm{ZnO}-\mathrm{HfO}_{2}$ system, and a deconvolution of the emission spectrum.

(a)

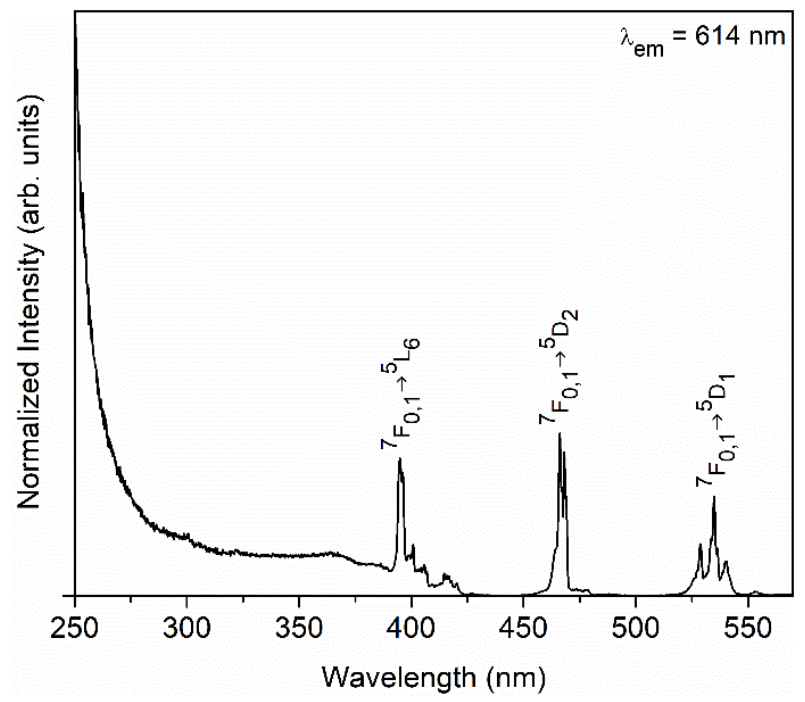

(b)

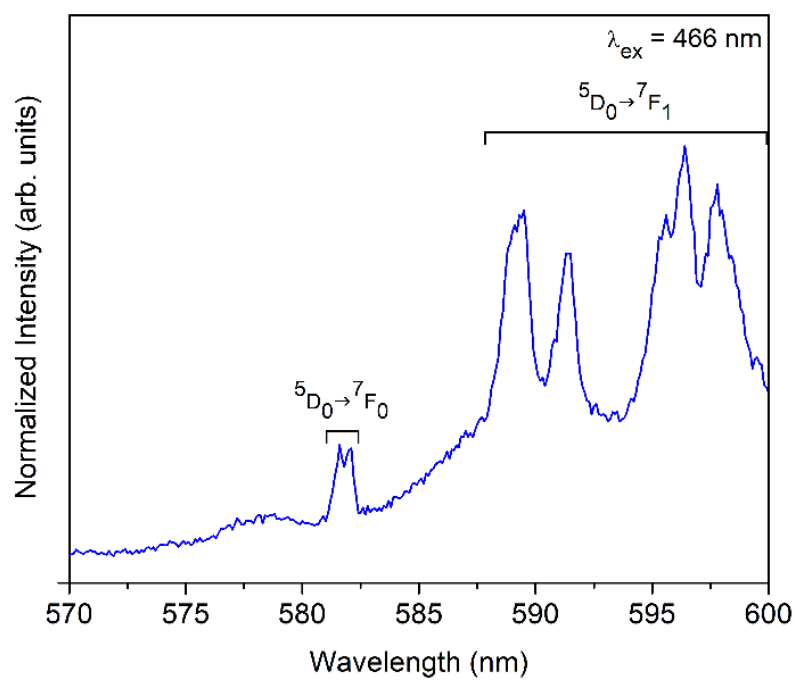

Figure S16. Photoluminescence (a) excitation and (b) emission spectra of $\mathrm{ZnO}-\mathrm{ZrO}_{2}: \mathrm{Eu}^{3+}$ $(1 \mathrm{~mol} \%)$. 
(a)

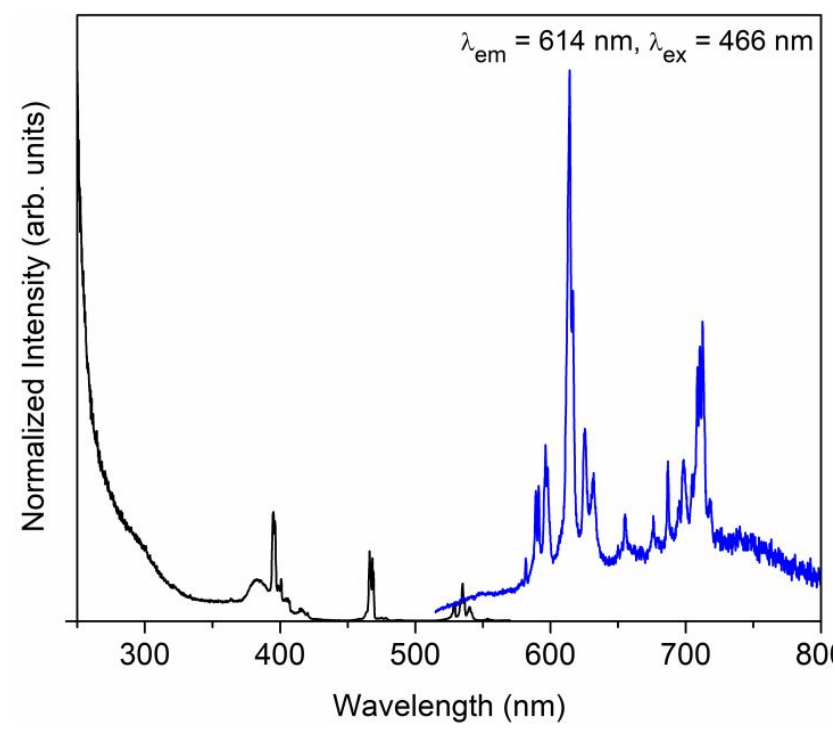

(c)

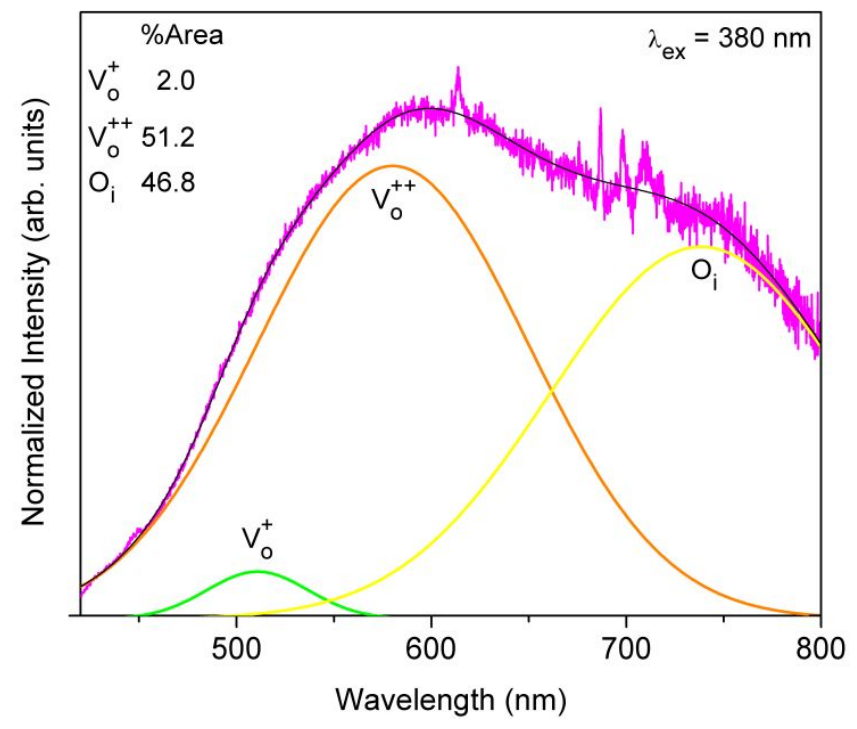

(b)

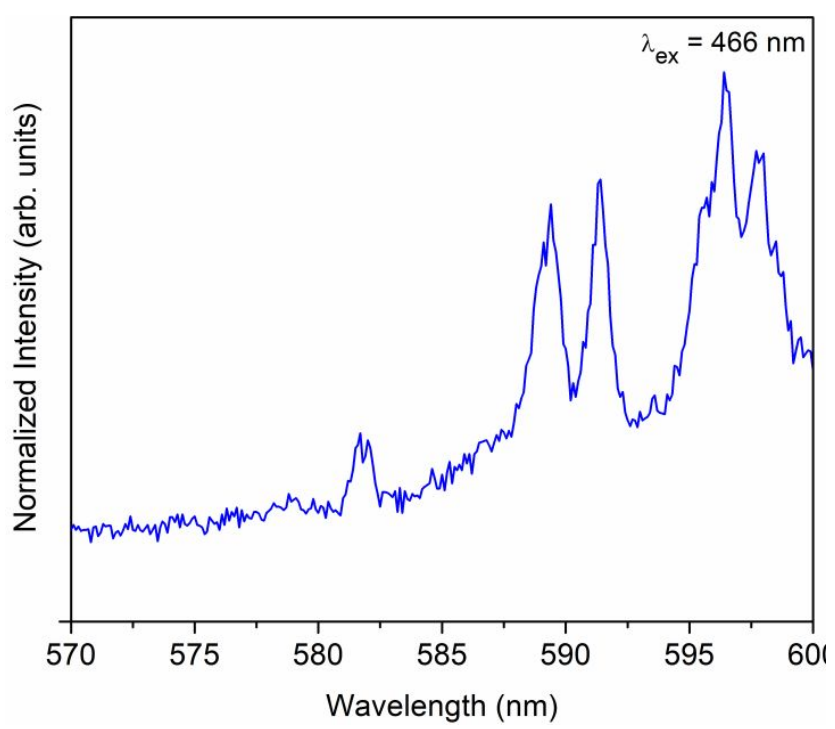

Figure S17. (a) Photoluminescence excitation and emission spectra of $\mathrm{ZnO}-\mathrm{ZrO}_{2}: \mathrm{Eu}^{3+}(2 \mathrm{~mol} \%)$. (b) Photoluminescence emission spectrum of $\mathrm{ZnO}-\mathrm{ZrO}_{2}: \mathrm{Eu}^{3+}$ (2 mol\%). (c) Photoluminescence emission spectrum of $\mathrm{ZnO}-\mathrm{ZrO}_{2}: \mathrm{Eu}^{3+}(2 \mathrm{~mol} \%)$ and its deconvolution. 
(a)

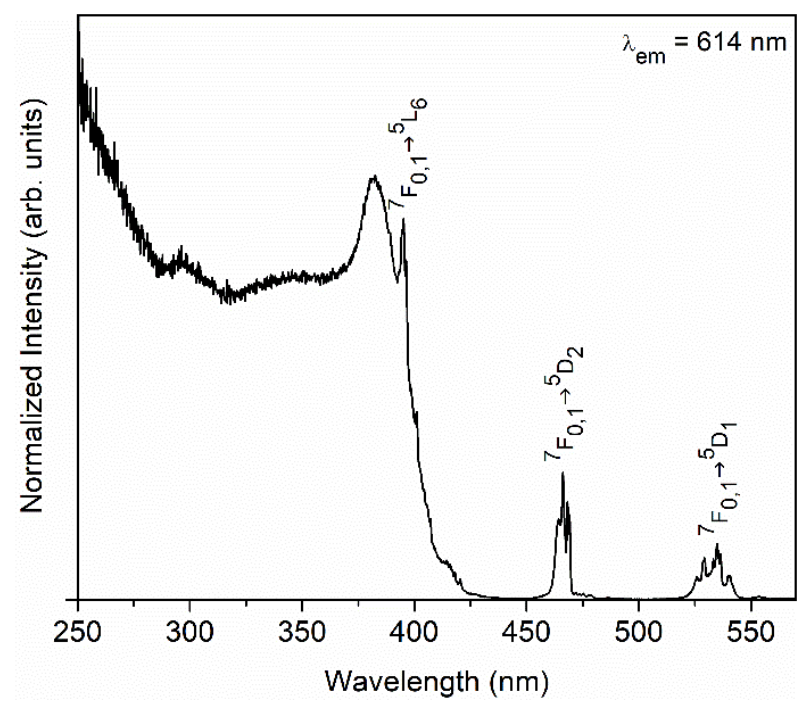

(b)

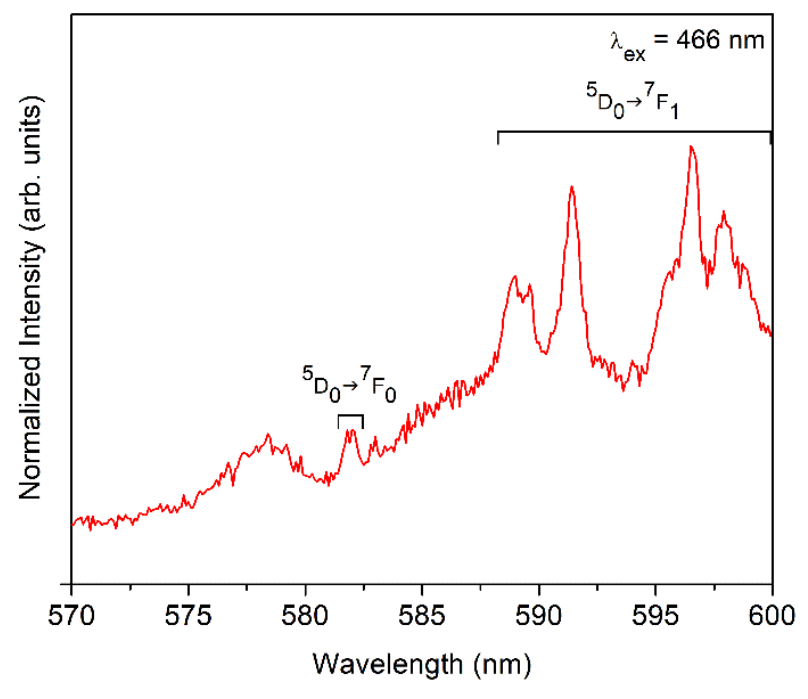

Figure S18. Photoluminescence (a) excitation and (b) emission spectra of $\mathrm{ZnO}-\mathrm{HfO}_{2}: \mathrm{Eu}^{3+}(1 \mathrm{~mol} \%)$. 
(a)

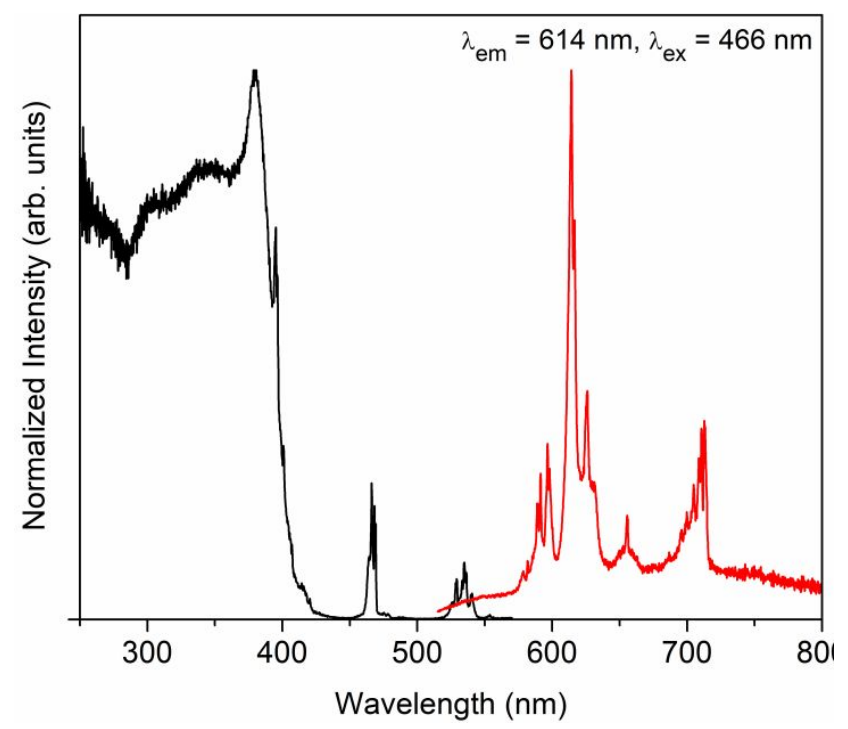

(c)

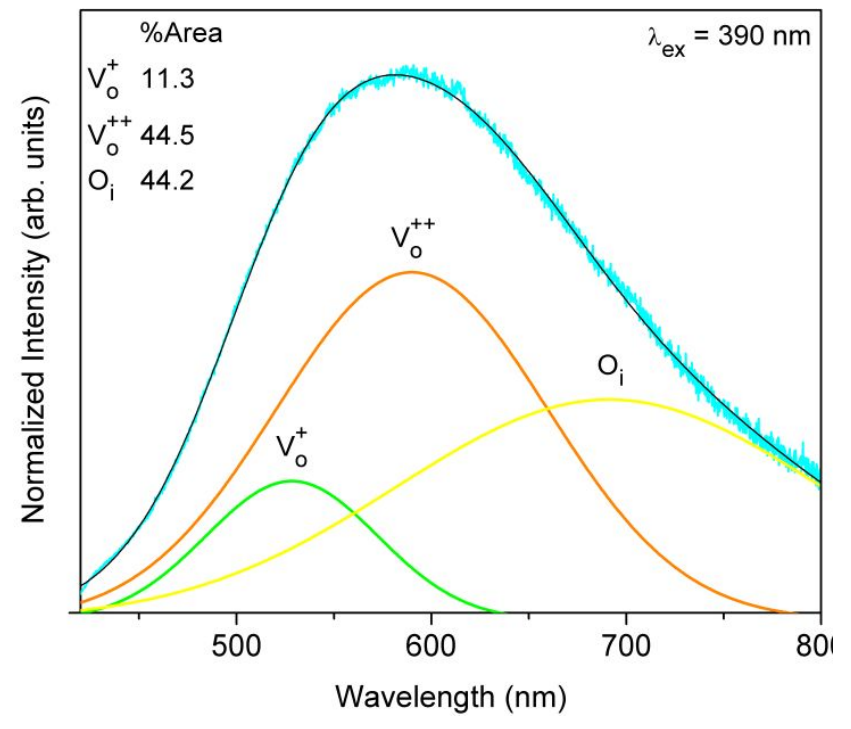

(b)

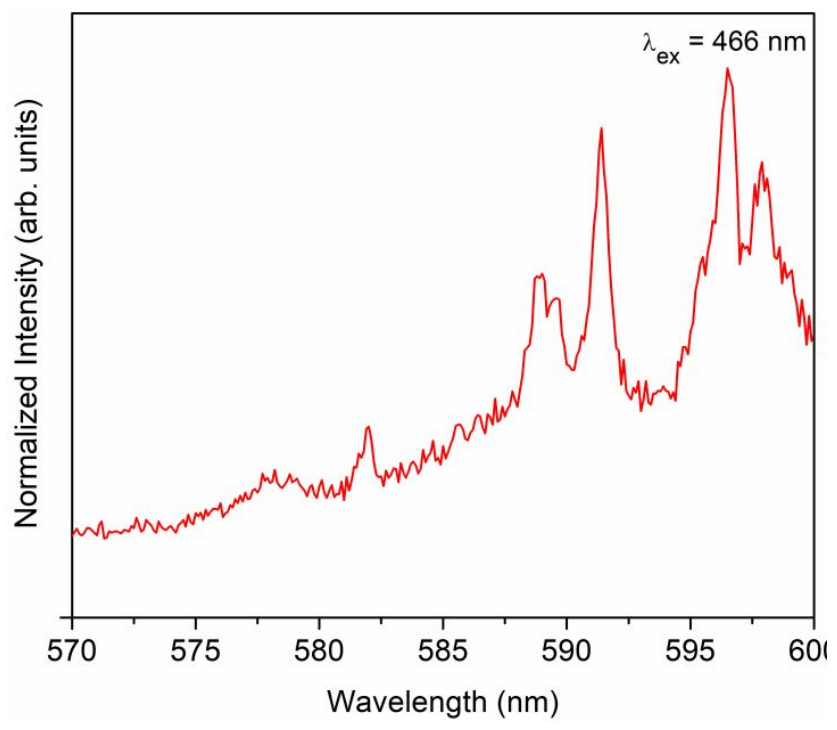

Figure S19. (a) Photoluminescence excitation and emission spectra of $\mathrm{ZnO}-\mathrm{HfO}_{2}: \mathrm{Eu}^{3+}(2$ mol\%). (b) Photoluminescence emission spectrum of $\mathrm{ZnO}-\mathrm{HfO}_{2}: \mathrm{Eu}^{3+}(2 \mathrm{~mol} \%)$. (c) Photoluminescence emission spectrum of $\mathrm{ZnO}-\mathrm{HfO}_{2}: \mathrm{Eu}^{3+}(2 \mathrm{~mol} \%)$ and its deconvolution. 
(a)

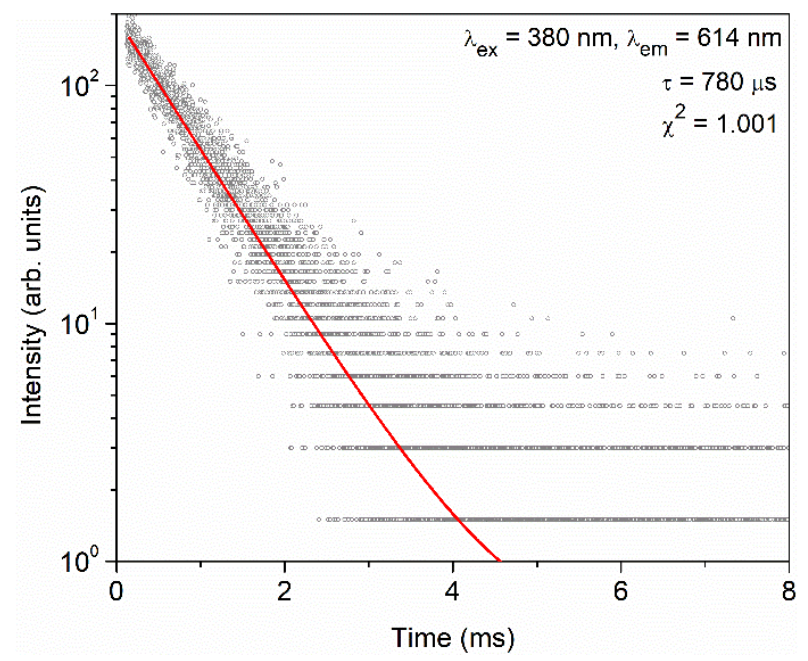

(b)

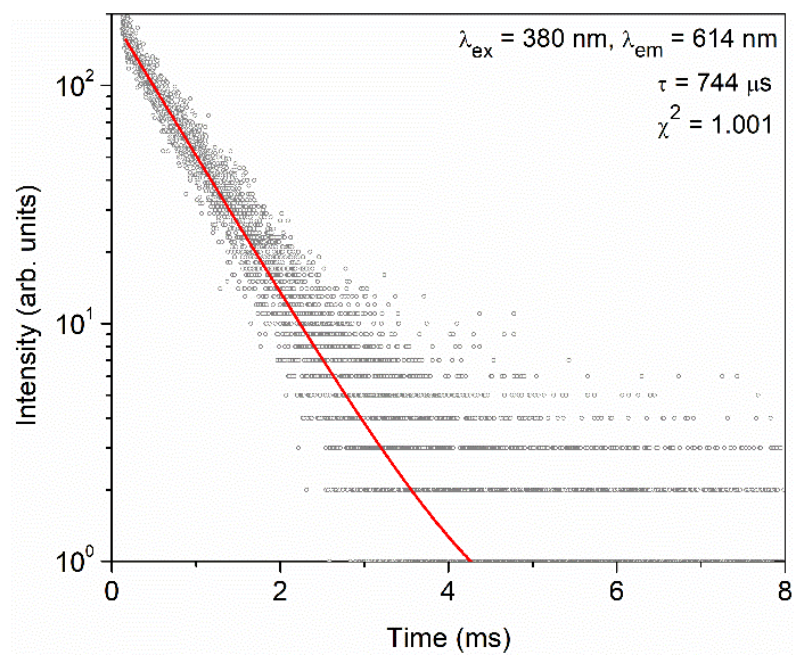

Figure S20. Luminescence decay curves (gray circles) together with fitting curves (red solid lines) for (a) $\mathrm{ZnO}-\mathrm{ZrO}_{2}: \mathrm{Eu}^{3+}$ (1 mol\%) and (b) $\mathrm{ZnO}-\mathrm{ZrO}_{2}: \mathrm{Eu}^{3+}$ (2 mol\%).

(a)

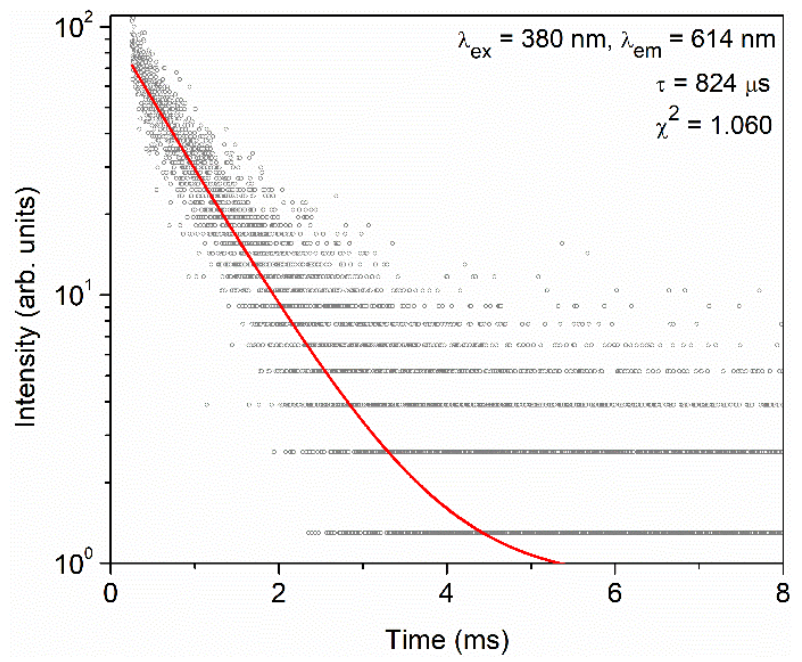

(b)

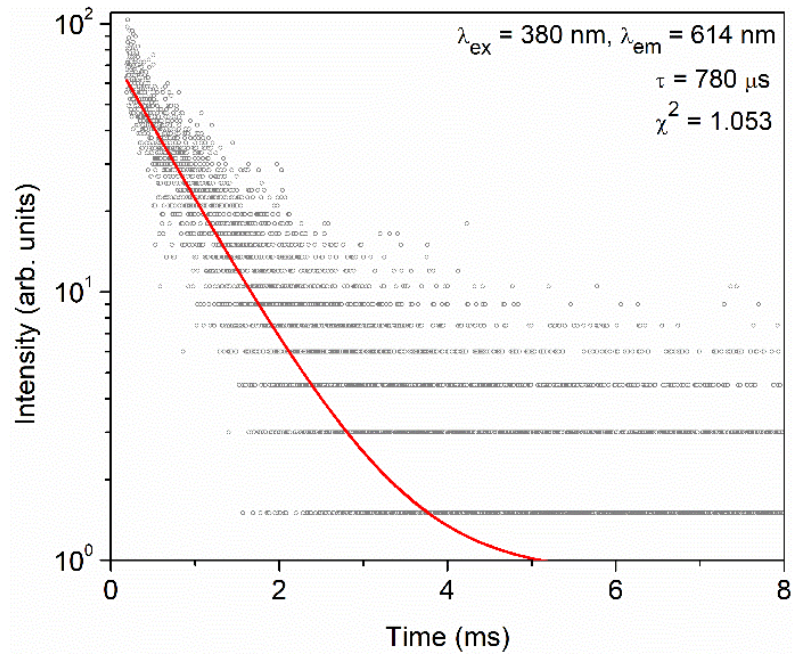

Figure S21. Luminescence decay curves (gray circles) together with fitting curves (red solid lines) for (a) $\mathrm{ZnO}-\mathrm{HfO}_{2}: \mathrm{Eu}^{3+}\left(1 \mathrm{~mol} \%\right.$ ) and (b) $\mathrm{ZnO}-\mathrm{HfO}_{2}: \mathrm{Eu}^{3+}(2 \mathrm{~mol} \%)$. 